\title{
An unusual opacity on an abdominal x-ray in a newborn
}

\author{
Indranil Misra, Gokul Erumbala \\ Department of Paediatrics, Milton Keynes Hospital NHS Foundation Trust, Milton Keynes, UK
}

Correspondence to Dr Indranil Misra, indranilmisra@doctors.org.uk

\section{DESCRIPTION}

A baby boy born at $31^{+1}$ weeks gestational age, had mild respiratory distress following birth that required continuous positive airway pressure. Antenatal scan at $20^{+2}$ weeks did not report any fetal anomalies and demonstrated normal liquor volume; no further antenatal ultrasound scans were carried out until delivery. Postnatal physical examination demonstrated some fullness on palpation of the lower abdomen. An abdominal x-ray, performed at $3 \mathrm{~h}$ of age to check the position of the umbilical catheters, showed an unusual opacity in the lower abdomen (figure 1). An urgent cot-side abdominal ultrasound confirmed distended bladder with thick and trabaculated wall, which was emptied via catheterisation. A diagnosis of posterior urethral valve (PUV) was confirmed by micturating

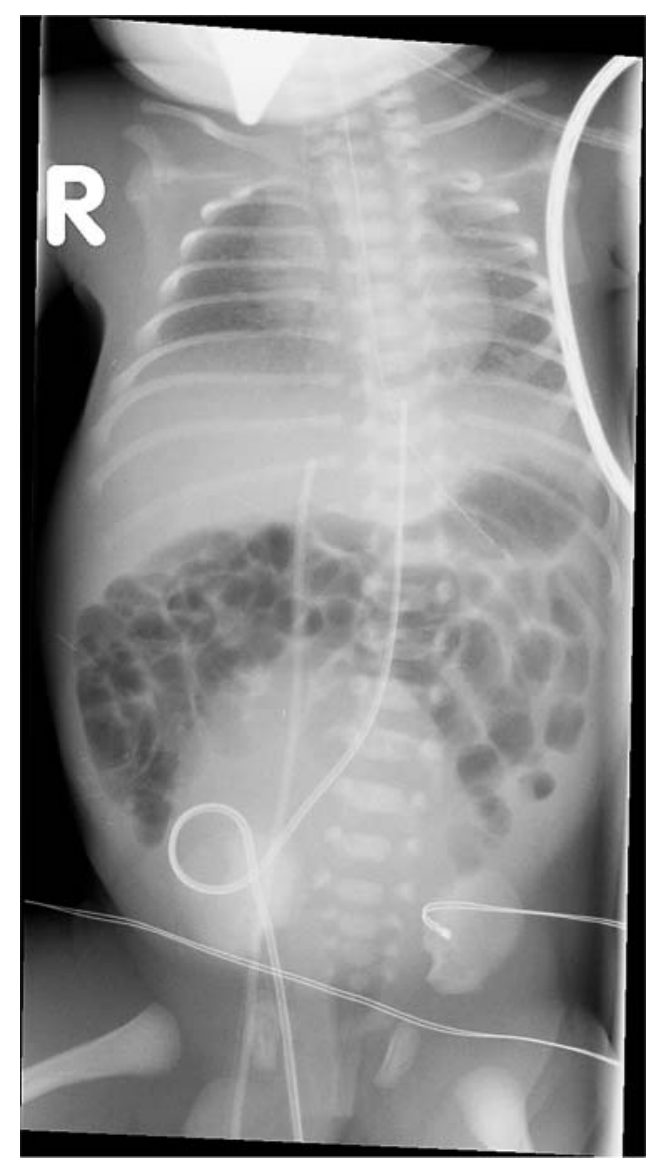

Figure 1 Abdominal x-ray demonstrating distended bladder, secondary to the posterior urethral valve. cysto-urethrogram, which also showed grade- 5 intrarenal reflux on the right side. He underwent suprapubic vesicostomy and endoscopic valve resection at 2 weeks of postnatal age. Suprapubic vesicostomy was reversed 2 months later when the baby was near term. He had normal renal function throughout. He was started on prophylactic trimethoprim and was discharged with plan for paediatric urology follow-up. A follow-up ultrasound scan performed at 1 month of age showed resolved calyceal dilation with both kidneys of normal size and echo texture.

Dilation of the fetal urinary tract usually results from obstruction, but in some cases it may be seen without evidence of obstruction. ${ }^{1}$ The differential diagnosis in cases of fetal urinary tract distention includes obstructive uropathy such as PUVs and other types of urethral obstruction, primary vesicoureteral reflux, prune belly syndrome, megacystis-microcolon-hypoperistalsis syndrome (a rare congenital autosomal recessive condition characterised by non-obstructive bladder distention, hydronephrosis, hydroureter, intestinal hypoperistalsis and microcolon ${ }^{2}$ ) and neurogenic bladder. ${ }^{3}$ Detection of an enlarged urinary bladder in a neonate warrants careful evaluation of the ureter, kidneys, genitalia and spine. Congenital bladder perforation, with neonatal urinary ascites, can be a rare complication associated with bladder outlet obstruction such as PUVs. ${ }^{4}$

The incidence of PUV is about $1: 2500-4000$ of live male infants. ${ }^{5}$ It is usually diagnosed on antenatal ultrasound scan at second trimester based on a persistently dilated bladder, upper tract dilatation with or without oligohydramnios. ${ }^{5}$ However, there are reports of PUV diagnosed at birth with normal antenatal scan as late as $31^{+6}$ weeks of gestational age. ${ }^{6}$ It is believed that development of significant obstruction at later part of pregnancy rather than earlier, carries a better prognosis. ${ }^{7}$ A high index of suspicion leading to prompt postnatal diagnosis and early decompression is advisable for a better outcome in late-presenters.

\section{Learning points}

- Posterior urethral valve is described in neonates who had normal third trimester antenatal scans.

- While obstructive uropathy is a common cause of dilated urinary tract, other aetiological factors should also be considered.

- Once identified, prompt bladder emptying should be carried out. Bladder rupture and urinary ascites can be a complication of undetected obstructive uropathy. 


\section{BMJ Case Reports}

\section{Competing interests None.}

Patient consent Obtained.

\section{REFERENCES}

1. Mahony BS, Callen PW, Filly RA. Fetal urethral obstruction: US evaluation. Radiology 1985:157:221-4.

2. Berdon WE, Baker DH, Blane WA. Megacystis-microcolon-intestinal hypoperistalsis syndrome: a new case of intestinal obstruction in the newborn-report of radiological findings in five newborn girls. AJR Am J Roentgenol 1976;126:957-64.

3. Osborne NG, Bonilla-Musoles F, Machado LE, et al. Fetal megacystis: differential diagnosis. J Ultrasound Med 2011;30:833-41.
4. Sahdev S, Jhaveri RC, Vohra K, et al. Congenital bladder perforation and urinary ascites caused by posterior urethral valves: a case report. J Perinatol 1997;17:164-5.

5. Duffy PG, Chowdhary SK. Posterior urethral valve: the current perspective. J Indian Assoc Pediatr Surg 2003;8:169-74.

6. Moslehi J, Anthony Herndon CD, McKenna PH. Posterior urethral valves presented at birth despite normal prenatal ultrasound scans. Urology 2001;57:1178.

7. Hutton KA, Thomas DF, Arthur RJ, et al. Prenatally detected posterior urethral valves: is gestational age at detection a predictor of outcome? J Urol 1994;152:698-701.

This pdf has been created automatically from the final edited text and images.

Copyright 2012 BMJ Publishing Group. All rights reserved. For permission to reuse any of this content visit http://group.bmj.com/group/rights-licensing/permissions.

BMJ Case Report Fellows may re-use this article for personal use and teaching without any further permission.

Please cite this article as follows (you will need to access the article online to obtain the date of publication)

Misra I, Erumbala G. An unusual opacity on an abdominal x-ray in a newborn. BMJ Case Reports 2012;10.1136/bcr-2012-007289, Published XXX

Become a Fellow of BMJ Case Reports today and you can:

- Submit as many cases as you like

- Enjoy fast sympathetic peer review and rapid publication of accepted articles

- Access all the published articles

- Re-use any of the published material for personal use and teaching without further permission

For information on Institutional Fellowships contact consortiasales@bmjgroup.com

Visit casereports.bmj.com for more articles like this and to become a Fellow 